\title{
New combinations for two species in the genus Synima (Sapindaceae, Cupanieae) from Queensland (Australia)
}

\author{
Martin W. Callmander, Andrew J. Ford \& Sven Buerki
}

\begin{abstract}
CALLMANDER, M.W., A.J. FORD \& S. BUERKI (2020). New combinations for two species in the genus Synima (Sapindaceae, Cupanieae) from Queensland (Australia). Candollea 75: 241-244. In English, English abstract. DOI: http://dx.doi.org/10.15553/c2020v752a7

Synima Radlk. is a small genus of Sapindaceae distributed in Australia, Indonesia (Moluccas and Western New Guinea) and Papua New Guinea with three species currently accepted. The genus can be recognized by its crested scales on the petals, a pericarp that dries thin and wrinkled, and the seed which has a fleshy, yellow-orange sarcotesta that is either small and basal or \pm enclosing the seed. Previous taxonomic studies expressed doubts regarding the generic placement of two species belonging to the genus Sarcotoechia Radlk.: Sarcotoechia serrata S.T. Reynolds and Sarcotoechia heterophylla S.T. Reynolds. A phylogenetic framework has shown that Sarcotoechia is paraphyletic and Sarcotoechia serrata is sister to Synima. Further morphological evidence (e.g., crested petals) support the transfer of the latter two species to Synima and the new combinations are proposed here: Synima heterophylla (S.T. Reynolds) Callm. \& Buerki and Synima serrata (S.T. Reynolds) Callm. \& Buerki. A key to all species of Synima is presented.
\end{abstract}

\section{Keywords}

SAPINDACEAE - Cupanieae - Sarcotoechia - Synima - Australia - New combination

\footnotetext{
Adresses of the authors:

MWC: Conservatoire et Jardin botaniques de la Ville de Genève, ch. de l'Impératrice 1, C.P. 71, 1292 Chambésy, Switzerland.

E-mail: martin.callmander@ville-ge.ch

AJF: CSIRO Land and Water, Tropical Forest Research Centre, Atherton, Q1d 4883, Australia.

SB: Department of Biological Sciences, Boise State University, Boise, USA.
}

Submitted on June 5, 2020. Accepted on August 24, 2020.

First published online on October 29, 2020.

ISSN : 0373-2967 - Online ISSN : 2235-3658 - Candollea 75(2): 241-244 (2020) 


\section{Introduction}

Synima Radlk. is a small genus of Sapindaceae with currently three species recognized (Forster, 2006). All the species occur in north-east Queensland in Australia with $S$. cordieri (F. Muell.) Radlk. extending to Papua New Guinea and Indonesia (Moluccas and Western New Guinea) (Leenhouts \& Adema, 1994). Synima is morphologically closely related to Sarcotoechia Radlk. and Toechmia Radlk. based on their fruits with fleshy valves, hairy inside walls, and seeds usually bearing a small sarcotesta (Reynolds, 1985a: 176; see Adema et al., 1994 for a discussion on the use of sarcotesta instead of aril).

Buerki et al. (2012) published a phylogenetic framework aiming at testing generic monophyly in the Cupania group (corresponding mostly to the tribe Cupanieae Radlk.; Buerki et al., unpubl. data) by focusing on taxa in the southern Pacific islands. This study demonstrated that Synima belonged to clade B together with Sarcotoechia, and Toechmia (Buerki et al., 2012: 115, fig. 2B). Synima was inferred sister to the new genus Neoarytera Callm. et al. endemic to New Caledonia and Vanuatu (BUER KI et al., 2020), whereas Toechmia was shown to be sister to the SE Asian and Australian genus Mischocarpus Blume. Finally, Sarcotoechia was inferred to be paraphyletic with S. villosa S.T. Reynolds sister to the New Caledonian genus Storthocalyx Radlk. and S. serrata S.T. Reynolds sister to Synima. Although Sarcotoechia and Synima are morphologically closely related, they can be discriminated by their petal morphology. Synima has crested scales on petals (vs. no petal crests in Sarcotoechia), pericarp that dries thin and wrinkled (vs. not wrinkled) and the seed with a fleshy, yellow-orange sarcotesta that is either small and basal or \pm covering the seed (vs. sarcotesta rudimentary or absent) (REYNolds, 1985a, 1985b; Forster, 2006).

REYNolds (1985a: 184) has previously warranted some caution related to the generic placement of Sarcotoechia serrata and an allied species by stating that "Sarcotoechia serrata and $S$. heterophylla differ from all other species of Sarcotoechia in having serrate or serrulate leaflets, crispate indumentum, very small rudimentary aril [sarcotesta] and slightly larger seed. The testa also is dull compared to the shiny ones of other species and the fruit valves are not fleshy. Until more collections become available both these species are tentatively included under Sarcotoechia because the flowers, especially petals, are those of the genus. The fruits and seeds are unlike any other known Sapindaceae in Australia".

Based on RAdLKOFER (1931-1934: 1255, translated from Latin by R. Gereau), Synima is morphologically characterized by "a testa of the seed [that is] drupaceous [and] covered, except for the dorsal groove, with a fleshy layer of tissue almost adnate to the aril". With the description of two further species in the genus, we know that the sarcotesta is quite variable in Synima. Synima cordieri (F. Muell.) Radlk and S. reynoldsiae have seeds +/- entirely covered by the sarcotesta, whereas in
S. macrophylla S.T. Reynolds this structure is small and only at the base of the seed (Forster, 2006). Previous phylogenetic analyses provided strong evidence supporting convergent evolution of fruit morphology in Sapindaceae as shown by the polyphyly of tribes and genera, which were mostly established based on fruit characters (BUERKI et al., 2009). This is especially the case in the Cupania group where genera previously assigned to Cupanieae and Schleichereae based on contrasting fruit morphologies (mostly dehiscent fruits with ceraceous, coloured sarcotesta in Cupanieae vs. indehiscent fruit with fleshy, translucent sarcotesta in Schleichereae) were retrieved in the same clade (Buerki et al., 2009, 2011). Phylogenetic analyses of Malagasy taxa inferred species of Neotina Capuron previously classified as Cupanieae nested within species of Tinopsis Radlk. previously classified as Schleichereae (BUERKI et al., 2011). A more in-depth morphological analysis recovered distinct floral and vegetative characters supporting the phylogeny (BUERKI et al., 2011). What these examples provide is evidence that fruit morphology in Sapindaceae could be deceptive and that emphasis should be shifted towards flower morphology accompanied by key vegetative characters.

While describing both Sacrotoechia heterophylla and S. serrata in Sarcotoechia, Reynolds (1985a: 182, fig. 5C) described both species with petals having "scales densely crispate hairy", which contradicts her statement that the "petals are those of the genus [Sarcotoechia]" for both species (REYnolds, 1985a: 184). This flowering character is absent in Sarcotoechia and considered as a synapomorphy for Synima. Forster (2006) had the same dilemma in describing $S$. reynoldsiae, a species long known as Sacrotoechia sp., which he formally described in Synima based notably on the presence of crested scales on petals.

Transfer of Sacrotoechia heterophylla and S. serrata into the genus Synima satisfies monophyly of Sarcotoechia while also maintaining coherent generic morphologies. The new combinations Synima heterophylla (S.T. Reynolds) Callm. \& Buerki and S. serrata (S.T. Reynolds) Callm. \& Buerki are proposed.

\section{Key to the genus Synima}

Adapted from Reynolds (1985b) and Forster (2006).

1. Leaflet margin uniformly serrate or serrulate; indumentum of crispate hairs; sarcotesta minute or absent ....... 2

1a. Leaflet margin entire or with occasional teeth towards apex; indumentum of straight hairs; sarcotesta larger .....

2. Leaflets $3-6$ pairs, regularly serrate, $2-5.5 \mathrm{~cm}$ long, $1.2-2.5 \mathrm{~cm}$ wide S. serrata

2a. Leaflets 2 or 3 pairs, irregularly and apically serrate or serrulate, $5.5-12 \mathrm{~cm}$ long, $2.5-4.2 \mathrm{~cm}$ wide 

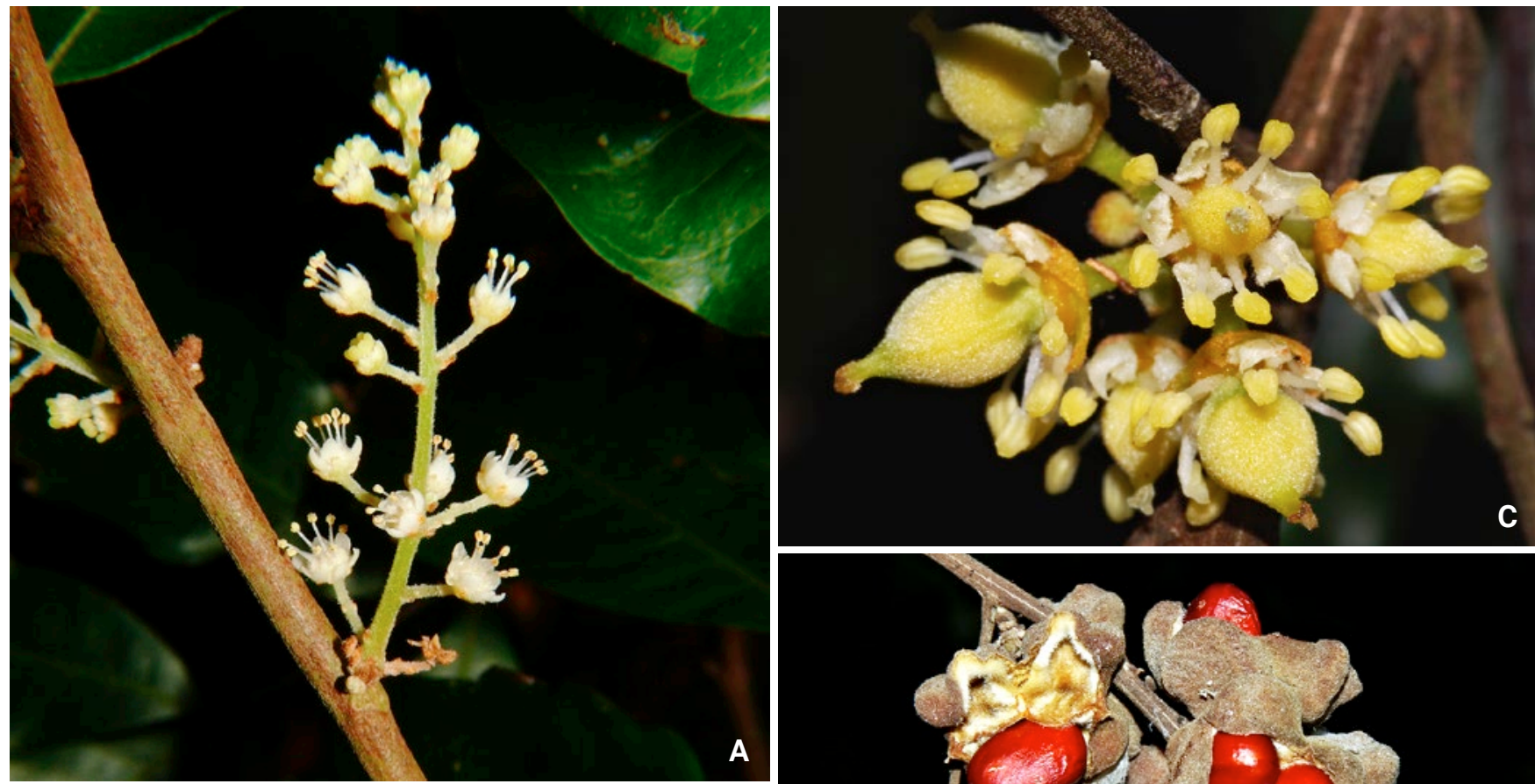

A
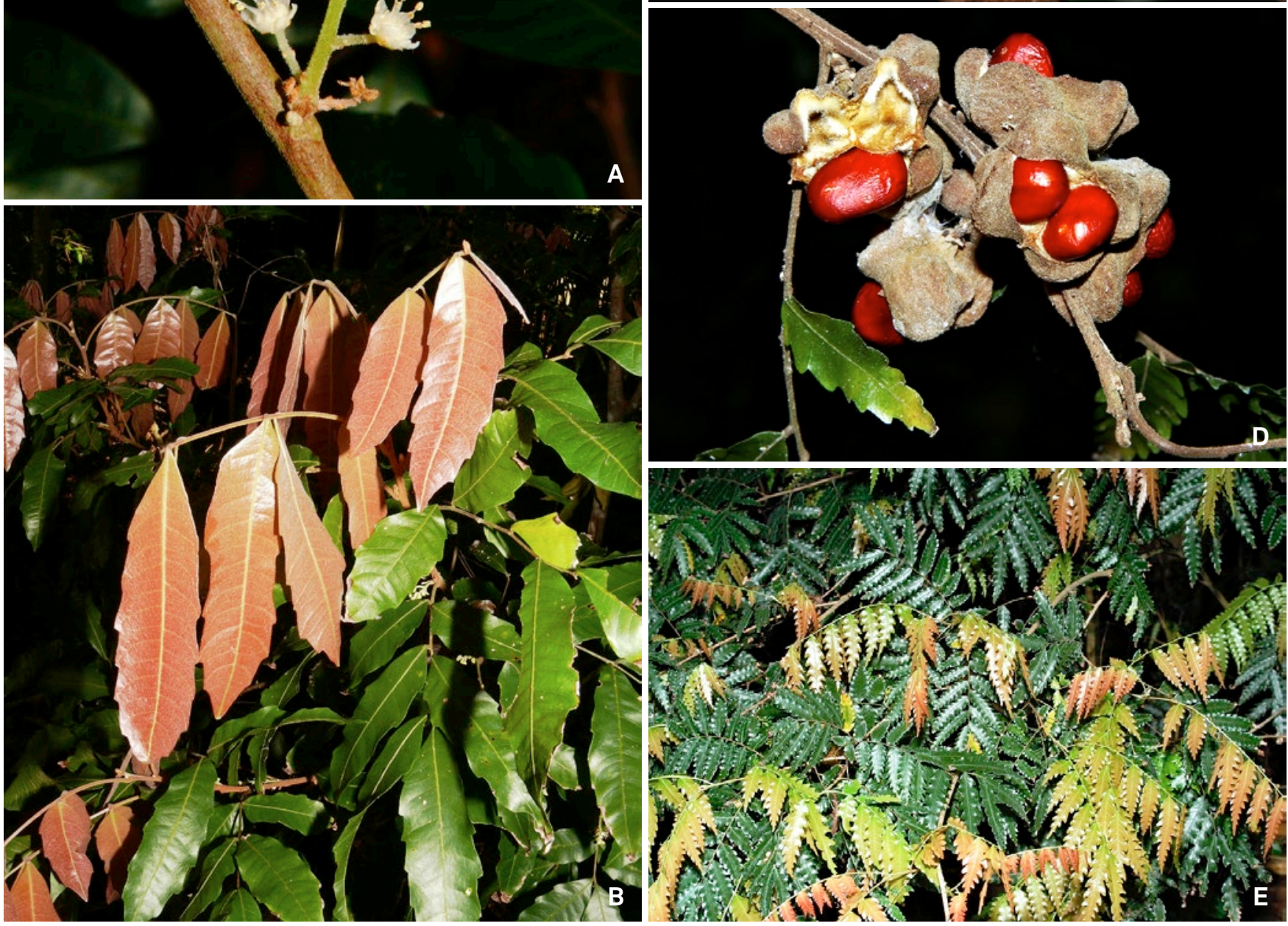

Fig. 1. - Synima heterophylla (S.T. Reynolds) Callm. \& Buerki: A. Inflorescence; B. Branch with juvenile and older leaves. Synima serrata (S.T. Reynolds) Callm. \& Buerki: C. Inflorescence; D. Mature fruits; E. Branch with juvenile and older leaves. [A-B: cultivated tree in Airlie Beach from seeds originating from Eungella (West of Mackay, Queensland); C-E: cultivated tree in Atherthon from seeds originating from Gadgarra (Atherthon Tableland, Queensland)] [Photos: A-B: S. and A. Pearson; C-E: G. Sankowsky] 
3. Branchlets 6-10 $\mathrm{mm}$ in diam.; inflorescences unbranched, or with only 1 to 3 side branches; cymules subsessile; sarcotesta covering only base of seed S. macrophylla

3a. Branchlets less than $5 \mathrm{~mm}$ diameter; inflorescences paniculate; cymules pedunculate; sarcotesta covering lower third or nearly whole of seed

4. Petals slightly keeled, with scattered to localised sparse indumentum externally, with uncrested scales; fruit obovoid, valve sutures white; leaflet midvein raised adaxially

S. cordieri

4a. Petals not keeled, with dense indumentum externally with crested scales; fruit subglobose, valve sutures yellowish; leaflet midvein flush adaxially S. reynoldsiae

\section{Taxonomy}

Synima heterophylla (S.T. Reynolds) Callm. \& Buerki, comb. nov. (Fig. 1A-B).

$\equiv$ Sarcotoechia heterophylla S.T. Reynolds, Fl. Australia 25: 201. 1985.

Holotypus: Australia. Queensland: South Kennedy pastoral distr., Eungella, 10.XI.1982, Williams 82244 (BRI [BRI-AQ0377732]!).

Note. - Synima heterophylla resembles $S$. serrata in having serrate leaves and crispate hairs. It can nevertheless be distinguished by its larger leaves $(5.5-12 \mathrm{~cm}$ long, $2.5-4.2 \mathrm{~cm}$ wide vs. $2-5.5 \mathrm{~cm}$ long, $1-2.5 \mathrm{~cm}$ wide in $S$. serrata), having some leaflets with irregularly serrate margin (vs. always regularly serrate) and sarcotesta nearly absent (vs. rudimentary) (REynOlds, 1985b).

Synima serrata (S.T. Reynolds) Callm. \& Buerki, comb. nov. (Fig. 1C-E).

$\equiv$ Sarcotoechia serrata S.T. Reynolds, Fl. Australia 25: 201. 1985.

Holotypus: Australia. Queensland: Cook distr., Gadgarra, IX.1954, White 895 (BRI [BRI-AQ0010264]!; iso-: CANB [CANB242040, CANB242041] images seen, L [L0014599]!, CNS [QRS501879]).

Note. - Synima serrata can be easily distinguished in Synima by its 3-6 pairs of deeply serrate leaflets, the crispate indumentum and the rudimentary sarcotesta (REYNOLDs, 1985b).

\section{Acknowledgements}

The first author wishes to thank Paul Forster (BRI) and Frank Zich (CNS) for their help in their respective herbaria and Bruce and Joy Gray for their wonderful hospitality in
Atherton and Yee Wen Low for the valuable time in Queensland. MC and SB are also very grateful to the Idaho Botanical Research Foundation for generous support of fieldwork, Chris Davidson and Sharon Christoph for their enthusiasm in following our research, Roy Gereau for his help in translating Radlkofer's Latin diagnoses into English and Pete Lowry and Jérôme Munzinger for fruitful discussions. We finally thank Steve and Alison Pearson and Garry Sankowsky for allowing us to publish their pictures and Paul Forster and Frank Zich for improving an earlier version of this manuscript.

\section{References}

Adema, F., P.W. Leenhouts \& P.C. Van Welzen (1994). Sapindaceae [introductory essay]. Fl. Malesiana ser. 1, 11(3): 419-768.

Buer ki, S., F. Forest, P. Acevedo-Rodriguez, M.W. Callmander, J.A. Nylander, M. Harrington, P. Kupfer \& N. Alvarez (2009). Worldwide phylogeny of the soapberry family (Sapindaceae): plastid and nuclear markers reveal intricate relationships at subfamilial, tribal and generic levels. Mol. Phylogenet. Evol. 51: 238-258.

Buerki, S., P.P. Lowry II, S. Andriambololonera, P.B. Phillipson, L. Vary \& M.W. Callmander (2011). How to kill two genera with one tree: clarifying generic circumscriptions in an endemic Malagasy clade of Sapindaceae. Bot. J. Linn. Soc. 165: 223-234.

Buerki, S., F. Forest, M.W. Callmander, P.P. Lowry II, D.S. Devey \& J. Munzinger (2012). Phylogenetic inference of New Caledonian lineages of Sapindaceae: molecular evidence requires a reassessment of generic circumscriptions. Taxon 61: 109-119.

Buerki, S., J. Munzinger, P.P. Lowry II \& M.W. Callmander (2020). Two new genera of Sapindaceae (Cupanieae) from the southern Pacific: Lepidocupania and Neoarytera. Candollea 75 : 269-284.

Leenhouts, P.W. \& F. Adema (1994). Synima. In: Adema, F. et al., Fl. Malesiana ser. 1, 11(3): 730-732.

Forster, P.I. (2006). Synima reynoldsiae P.I. Forst. (Sapindaceae), a new species from the 'Wet Tropics' of north-east Queensland. Austrobaileya 7: 285-291.

Radlkofer, L. (1931-1934). Sapindaceae. In: Engler, A. (ed.), Das Pfanzenreich 98a-h. W. Engelmann, Leipzig.

Reynolds, S.T. (1985a). Notes on Sapindaceae IV. Austrobaileya 2: 153-189.

Reynolds, S.T. (1985b). Sapindaceae. In: George, A.S. (ed.), Fl. Australia 25: 4-215. 